\title{
A DISTORÇÃO DO EQUILÍBRIO ENTRE OS PODERES PROMOVIDA PELA SUPREMA CORTE E O SURGIMENTO DO SEMIPRESIDENCIALISMO DE LIMINARES NA REPÚBLICA BRASILEIRA
}

\author{
THE DISTORTION OF THE BALANCE BETWEEN THE POWERS PROMOTED BY THE \\ SUPREME COURT AND THE EMERGENCE OF THE SEMI-PRESIDENTIALISM OF \\ INJUNCTIONS IN THE BRAZILIAN REPUBLIC
}

Julierme Veras de Moura ${ }^{1}$

\begin{abstract}
Resumo: Rompendo com a tradicional abordagem política sobre as formas de Sistema de Governo de uma República (Presidencialismo, Parlamentarismo e Semipresidencialismo) a dimensão do equilíbrio entre os poderes tem sido corrompida, no Brasil, da sua forma perfeita proposta por Montesquieu, fenômeno que ganhou força desde a promulgação da Constituição Federal de 1988 e atingiu níveis nunca vistos no início do Século XXI. Embora não esteja escrita de forma diferente de como está sendo executada, esta dimensão é crucial para a compreensão do fenômeno de mudança do Sistema de Governo do Brasil. Sendo necessária uma pesquisa bibliográfica, no intuito de, mediante informações de Leis, livros, periódicos, matérias e artigos da internet, reunindo dados e informações, que servirão de base para construir o argumento de que com as diversas ações e intervenções perpetradas pelo Supremo Tribunal Federal, implantou um sistema de governo que fere nosso arcabouço constitucional.
\end{abstract}

Palavras-Chave: Semipresidencialismo; Constituição Federal; Sistema de Governo.

\begin{abstract}
Breaking with the traditional political approach on the forms of Government System of a Republic (Presidentialism, Parliamentarianism and Semi-Presidentialism), the dimension of the balance between powers has been corrupted, in Brazil, from its perfect form proposed by Montesquieu, a phenomenon that has gained strength since the promulgation of the Federal Constitution of 1988 and reached levels never seen in the beginning of the 21 st century. Although it is not written differently from how it is being executed, this dimension is crucial for understanding the phenomenon of change in the System of Government in Brazil. Bibliographical research is necessary, in order to, through information from Laws, books, periodicals, matters and articles on the internet, gathering data and information, which will serve as a basis to build the argument that with the various actions and interventions perpetrated by the Supreme Court Federal, implemented a system of government that violates our constitutional framework
\end{abstract}

Keywords: Semi-presidentialism; Federal Constitution; Government system.

\footnotetext{
${ }^{1}$ Major da Polícia Militar de Pernambuco, Bacharel em Sistemas de Informações pela FIR, Especialista em Formação de Educadores pela UFRPE, Especialista em Gestão de Segurança Pública pela FACIPE, Especialista em Gestão Governamental pela FACINTER. E-mail: julierme20@ hotmail.com
} 


\section{Introdução}

Ao longo da história vários modelos de Estado e de governo foram sendo apresentados ao público, uns modelos mais concentradores, outros menos, como podemos verificar desde o regime deificado do antigo Egito, passando pela democracia grega e a república romana, chegando nas monarquias europeias, até o surgimento das repúblicas modernas, pós Independência Americana e a Revolução Francesa. Vemos com isso, que o exercício do poder para a administração de um determinado povo, sempre esteve no centro da discussão política, e nunca foi algo inerte.

$\mathrm{Na}$ modernidade, contrapondo-se as Monarquias Absolutistas surgem correntes de pensamento que tinham a intenção de dividir o poder de governar, retirando das mãos de um monarca, a exclusividade do exercício daquele poder, mediante a formulação da proposta de divisão daquele com outras duas instituições (poderes), assim surge o que conhecemos como sendo o conceito moderno da tripartição dos poderes, no qual limitava o exercício do poder por uma única pessoa, já que quando alguém, ou alguma instituição tem poder, o exercício desse poder vai ser efetivado, e conforme é dito "todo homem que tem o poder é tentado a abusar dele (...) é preciso que pela disposição das coisas o poder frei o poder", nessa nova concepção existiriam três poderes(Executivo, Legislativo e Judiciário) que seriam responsáveis pela condução do governo, sendo o Executivo - Responsável pela administração do território; o Legislativo - responsável pela elaboração das leis; e o Judiciário - responsável pela fiscalização do cumprimento das leis , conforme consta na obra O Espírito das Leis (MONTESQUIEU, 2008), conceito que continua vigente até os dias atuais nas democracias contemporâneas. Haja vista, que é indispensável que tais poderes sejam limitados pela lei, dentro do princípio da liberdade e igualdade, conforme defendido pelo liberalismo político, na medida em que esse ordenamento jurídico deva garantir a independência e a harmonia entre esses mesmos poderes, evitando que haja a possibilidade de um poder extrapolar suas atribuições, fato que abriria a possibilidades dos poderes iniciarem um processo de interferências múltiplas no intuito de conter o avanço.

O Brasil costuma nos agraciar com alguns estados de coisas peculiares, as quais as diferenciam daquelas outras coisas que serviram de modelo para serem implementadas, e tais peculiaridades brasileiras somam-se ao longo da nossa história contribuindo para o estado de coisas atual. Um dos exemplos que podemos trazer é a figura do poder moderador no imaginário brasileiro, poder que foi formalizado pela Constituição de 1824, esse Poder Moderador, que seria um quarto poder (Moderador , Executivo, Legislativo e Judiciário), residiria nas mãos do Monarca, que poderia intervir 
livremente nos demais poderes do Império. Essa cultura intervencionista, ou concentradora de poder tem nos acompanhado até os dias atuais, de forma formalizada ou de forma tácita.

Destarte, após a Proclamação da República e a posterior promulgação da Constituição de 1891, foi adotado, no nosso país, o sistema presidencialista fundamentado na tripartição dos poderes, continuando assim, até a contemporaneidade, mesmo com alguns momentos de exceção, como o modelo da Constituição de 1937, que tratava o Presidente da República como Autoridade Suprema do Estado , a breve experiência parlamentar entre 1961 e 1963, e a mais recente , o caso da Constituição de 1967, que a tripartição dos poderes estava expressa , no texto, só que existia uma hipertrofia do poder executivo.

Com a abertura política e a promulgação da Constituição de 1988, foram abraçadas todas as demais Legislações e Tratados Internacionais no âmbito dos Direitos e Garantias Fundamentais dos Homens, que ratificou um novo momento político na sociedade brasileira, e dotou as instituições da legalidade necessária ao seu funcionamento em consonância com a existência do Estado Democrático de Direito.

\section{Peculiaridades brasileiras e a figura do poder moderador}

Aristóteles já nos dizia que "o todo é maior que a simples soma de suas partes", mas não conseguiremos tratar sobre o atual momento político brasileiro, sem abordar as diversas situações que terminaram por constituir o nosso imaginário político e que contribuem até os dias de hoje com a situação que nos encontramos. Nem tampouco, adianta analisar essa mesma situação sem irmos somando os fatos que ao longo dos anos foram construindo esse jogral que podemos perceber na atualidade. Algumas parcelas dessa soma, são essenciais para entender esse todo, sem as quais não teríamos tal resultado, assim temos: a figura de uma força (poder) intervencionista; o federalismo; o multipartidarismo; o presidencialismo; a Constituição de 1988; a proporcionalidade; e a coalizão ou governabilidade.

Essas parcelas da soma, produzem um resultado muito peculiar, algo só visto aqui em Pindorama, nossa república se diferencia das inúmeras outras repúblicas democráticas pelo mundo ocidental afora, cada uma contribuindo da sua forma para que tenhamos chegado aonde chegamos, todavia temos umas parcelas que contribuem mais fortemente que outras na composição desse todo, e o folclórico poder moderador é um que se destaca nesse contexto.

\section{O poder moderador, o Império e a estabilidade}


Uma dessas primeiras situações peculiares, é a presença folclórica do poder moderador, como sendo essa força ou poder intervencionista capaz de proporcionar a governabilidade ou a sobrevivência do governo, estando ele, expresso ou não, no nosso ordenamento constitucional, até mesmo porque a constituição vivida é diferente da constituição escrita.

No Brasil império essa concentração de poder nas mãos de um monarca, foi condição essencial para manter a unidade nacional, diferentemente da América espanhola, que se fragmentou em diversos países por toda América do Sul e Central. Mantendo essa tradição centralizadora, após a independência do Brasil, a figura do imperador no Brasil solidificou esse status quo, na medida em que a Carta Outorgada de 1824, formaliza o Poder Moderador. O que de antemão foi pensado pelo iluminista Benjamin Constant (Apud CAMPOS, 2019) para ser um Poder Neutro, aqui foi transfigurado num poder intervencionista, concentrado nas mãos do monarca, a ponto de no texto da retro mencionada constituição, era instituía a dinastia perpétua de Dom Pedro, com atributos de divindade, onde tal divindade era ratificada pela Igreja Católica, a qual era portadora da religião oficial do império. Talvez essa característica específica, tenha tornado essa constituição a mais longeva e a mais íntegra da história nacional, pois além de durar 65 anos e possuiu apenas uma emenda, fato que contribuiu fortemente para a figura do poder moderador no ideário nacional.

\section{A república, os militares e o poder da espada}

Com o advento da República, surge também um novo componente na nossa história, o presidencialismo, o qual seria o responsável pelo poder executivo, na tentativa de copiar a democracia americana. Entretanto a figura do poder moderador, como poder intervencionista, não desaparece por completo da nossa realidade vivida, pois mesmo não estando escrito no texto da constituição, permaneceu existindo no imaginário político da época. No primeiro momento os militares, que também tinham sido corresponsáveis pela deposição de Dom Pedro II, foram necessários para a manutenção do regime, e funcionaram como esse poder moderador (República da Espada 1889 a 1894).

Ao longo do tempo, esse poder folclórico foi passado de mão em mão, num primeiro momento (pós Proclamação da República) surgem os militares como poder moderador, que foram influenciados fortemente pelo positivismo de Augusto Comte. Assim, essa casta específica marca posição como um importante ator na governabilidade do país, pois além de terem sido corresponsáveis pela deposição do Imperador Dom Pedro II, agora estavam no centro do poder político brasileiro, e ainda se 
consideravam tutores da República, responsáveis pela evolução do país ,conforme nos mostra o Tenente Coronel Benjamin Constant :

\begin{abstract}
"O soldado deve ser, de hoje em diante, o cidadão armado, corporificação da honra nacional e importante cooperador do progresso com garantia da ordem e da paz públicas". Na sua visão positivista, o exército não era um mero participante do progresso, e sim o autêntico vanguardista na consecução do estado positivista, pois dizia "Um exército enfim que, correspondendo às legítimas aspirações nacionais, instalou e firmou para sempre, em sólidas e largas bases, a República no seio da pátria por meio de uma revolução eminentemente pacífica e humanitária" (...) É que eles obedecem consciente ou inconscientemente na sua índole, organização e nos seus destinos a leis imperturbáveis reguladoras da evolução geral do progresso humano que tende inevitável e progressivamente para o feliz regime final - industrial e pacífico - resultante do fraternal congraçamento dos povos. (...) Para ele concorrerá poderosamente o exército brasileiro a que me orgulho pertencer." (CONSTANT Apud PAIM,2017):
\end{abstract}

\title{
O poder moderador, as oligarquias e o federalismo café com leite
}

Outra situação peculiar, que somada as outras, influenciam no resultado, é a do federalismo brasileiro, que foi ratificado na primeira constituição republicana, mudando a denominação do país para um homônimo americano (Estados Unidos do Brasil). Todavia, como de costume por aqui , a cópia não se assemelha muito ao produto original, visto que esse desenho institucional diferia e muito do americano, pois lá a situação em que a federação fora criada, é totalmente antagônica da brasileira, na América do Norte não existia poder central, pois o poder central era a coroa inglesa , então por ocasião da independência americana , os 13 Estados demandavam a criação de um governo central, para que conduzisse os rumos do país recém-instituído. Já por aqui, o governo central existia desde a chegada da Família Real em 1808. Ademais, já se passavam mais de 80 anos, em que o poder central nomeava os presidentes das províncias e ditava as políticas nacionais e regionais.

Como consequência disso, os estado membros eram meras extensões do poder do imperador , fazendo com que a federação partisse de um momento em que esses estados-membros tinham uma representatividade enfraquecida, da mesma forma que eram enfraquecidos também , os partidos políticos, pois não existiam partidos políticos com atuação nacional, já que atuavam de forma regionalizada.

Devido a esse cenário o poder que passou a moderar e dar sustentação a governabilidade, foi o poder financeiro, migrando para as oligarquias dos dois estados mais ricos do país, que também possuíam os dois partidos mais bem estruturados, que seriam o Partido Republicano Paulista e o Partido Republicano Mineiro, ambos se revezavam na indicação do Presidente da República, no período da política nacional conhecido com Política do Café com Leite, que perdurou até a ascensão 
de Vargas. Fica inconteste, essa influência como moderadora e promotora de governabilidade, pois no momento em que esse acordo tácito foi rompido, na sucessão de Washington Luiz (paulista), onde deveria ser sucedido por um mineiro, mas foi indicado por Washington Luiz o também paulista Júlio Prestes, o que provocou uma retaliação por parte dos republicanos mineiros aliados a outros estados brasileiros, findando assim, o acordo que fundamentava a governabilidade, abrindo caminho para o Golpe de 1930.

\section{O Caudilho, o tenentismo e as baionetas}

Por ocasião do Golpe de 1930, mais uma vez os militares aparecem como poder moderador, como garantidores do novo regime, para garantir a ascensão de Getúlio Vargas a presidência da república, esse poder garantidor trazia consigo outro ator que também bebeu em águas positivistas e estaria presente na política nacional até meados da década de 1970, esse novo ator era o Tenentismo, movimento que unia ideologicamente civis (oligarcas) e militares (tenentes), o tenentismo se torna um ator ideológico muito importante no nosso processo político. Tendo sido claramente confirmado como poder moderador, quando Vargas assume o poder e se preocupou em alocar alguns tenentistas nos mais diversos ministérios; como também, nomeou os tenentistas a frente dos estados-membros, na prática, os tenentistas compunham o gabinete(ministérios) e os governos dos estados (governadores), assim, os militares detinham o poder moderador e o federalismo ao mesmo tempo.

Durante nossa linha histórica, esse grupo ideológico, interviria algumas outras vezes na política nacional, mudando a personificação folclórica do poder moderador para a representação da figura dos militares, um dos exemplos disso, é que além de outras intervenções durante a história, em 1964, os tenentistas que outrora davam suporte ao governante escolhido, iniciaram um novo momento político nacional que durou 21 anos, e estavam agora a frente da República Federativa do Brasil, mais uma vez determinando seus destinos, só que dessa vez como comandantes, antes tenentes, agora generais presidentes, estando entre eles: Geisel, Eduardo Gomes, Medici, Castelo Branco, etc.

\section{A Constituição, a retirada dos militares e o poder difuso}

Mesmo considerando que os tenentistas tenham se retirado da política por ocasião do início da abertura política, e a promulgação da Constituição de 1988, os militares permaneceram como uma espécie de poder garantidor, para a transição democrática e o início da Nova República conforme nos mostra (ZAVERUCHA, 2000) em seu livro A Frágil Democracia, quando os militares , tacitamente , 
"autorizaram" o congresso a seguir com o afastamento do Presidente, no momento em que o Almirante Flores deu o tom do que seria o comportamento dos militares, dizendo que a discussão sobre o afastamento presidencial era precipitada, mas que as Forças Armadas apoiariam o Congresso. E ainda quando em reuniões secretas entre o Vice-Presidente, Itamar, com o almirante supracitado, ficou garantido que não haveria golpe por parte dos militares, caso houvesse o afastamento do Presidente. E como gratidão ao oficial da Marinha em questão, ele fora designado para a direção da Secretaria de Assuntos Estratégicos, que possuía status de ministério, junto com ele foram nomeados nove ministros militares em seu governo, além de outros tantos no segundo escalão.

Mesmo com a nova constituição não trazendo de forma expressa, a existência do poder moderador , o constituinte Yves Gandra Martins aparece como uma voz que nos apresenta as Forças Armadas como esse poder, visto que foi um dos responsáveis pela formulação do texto que trata dos instrumentos legais para a defesa do Estado e das instituições democráticas, e das instituições que tem as atribuições de proteger a democracia e os poderes constituídos. Ele afirma que por sua abrangência nacional e missão de proteção da soberania nacional, as Forças Armadas tiveram um tratamento diferenciado nos Artigos 142 e 143, que seriam: Defesa da pátria, a garantia dos poderes constitucionais, e a Garantia da lei e da ordem, por iniciativa de qualquer dos três Poderes. Na interpretação do mesmo Jurista, as Forças Armadas, quando acionadas por algum dos poderes, tem a competência de Poder moderador para reestabelecer (no ponto específico de um poder ter atropelado o outro) a ordem. Mesmo que alguns Juristas defendam o Supremo Tribunal Federal como poder Moderador, o citado constituinte alega que a situação não configura a realidade, pois caso o mesmo STF invadisse a competência de outro poder, tal poder invadido não poderia recorrer ao próprio poder invasor (MARTINS, 2020).

Verifica-se que os fatos em estudo apresentam que essa influência militar teve um ponto de inflexão com a eleição de Fernando Henrique Cardoso quando em sua fala ao se despedir do Senado disse: “Acontece que essas eleições colocaram, a meu ver, um ponto final na transição. Depois desses dezesseis anos de marchas e contra marchas, a abertura lenta e gradual do ex Presidente Geisel parece chegar ao ponto seguro de uma democracia consolidada"(ZAVERUCHA,2000). Mesmo ainda recorrendo a alguns apoios militares, aos poucos o governo FHC foi mudando o cenário quanto ao poder garantidor da governabilidade, pois o país já dispunha de todas as outra partes constituintes da nossa democracia, e que também já foram citadas, como: o federalismo; o multipartidarismo; o presidencialismo; a Constituição de 1988; a proporcionalidade.

Procurando reduzir a influência dos militares nos desígnios da nação, FHC promove uma mudança que contribuiria para isso, assim o governo federal, mudou o status quo do serviço de 
inteligência brasileiro, criando a ABIN e a outra, ao lançar a Política de Defesa Nacional(PDN), que entre outras ações extinguia o viés ideológico da figura do inimigo interno.

Assim o poder moderador exercido pelos militares foi sendo arrefecido, excluindo-se assim, uma parcela importante daquela soma que funciona como a equação que determina nosso estado de coisa atual. Pois como nos mostra a história, não existe vácuo de poder, pois se alguém desiste de assumi-lo, outrem o fará, devendo o detentor do poder ocupar todos os seus espaços. Mesmo com a redação do Artigo 142 da constituição de 1988, a aludida Carta esvaziou a influência dos militares, e ainda, apresentando instrumentos parlamentaristas, contribuiu com o aparecimento de um poder mais difuso, ora na mão do executivo, ora nas mãos do legislativo, demandando com isso, uma nova forma de conduzir o governo.

Surgiram novas situações peculiares na condução da governabilidade do país com o advento da nova Constituição, pois o executivo (chefe de governo) adquiriu a possibilidade de legislar por intermédio da iniciativa privativa do Presidente da República para projetos de leis sobre determinados assuntos, como também por meio de Medidas Provisórias, transformando o poder executivo na mola propulsora da agenda legislativa. E proporcionou ao Congresso a participação direta na tomada de decisão sobre medidas de cunho eminentemente governamental, como: a formulação de programas de governo e a estruturação dos ministérios e demais órgãos da administração direta. Além de não ter vedado a participação de congressistas na composição dos ministérios do poder executivo, diferenciado do presidencialismo americano, que veda essa participação.

Da mesma forma que o quem detêm o poder é tentado a abusar dele; aquele que avalia ter a expectativa de direito de exercer o poder, vai atuar para exercê-lo. Em virtude de o poder penetrar os vazios em silêncio, como gás, sem chamar atenção, sem fazer estardalhaço, até estar pronto para mostrar sua face. Essa composição de fatores contribuiu para que o mecanismo da política surgisse com um novo modelo de poder moderador a "Coalizão" o que foi definido como sendo o Presidencialismo de Coalizão (ABRANCHES, 2018).

Podemos tratar essa nova forma de presidencialismo, como uma das formas de presidencialismo imperfeito, sendo a segunda forma de presidencialismo imperfeito, o Semipresidencialismo de liminares. No primeiro modelo de presidencialismo imperfeito o Presidente precisa de uma coalizão para governar, que normalmente é construída com uma base de governo composta pela maior quantidade de cadeiras parlamentares possíveis, formando assim, a maior bancada da Câmara, mediante a cessão de espaços no poder executivo para os congressistas , que compõem a tal base governista. 
O que provocaria essa necessidade de concessão de espaços no executivo, é a existência de cinco elementos institucionais, peculiares ao Brasil , que de certa forma , citados acima os quais são: presidencialismo, o federalismo, o bicameralismo, o multipartidarismo e a representação proporcional.“ Não existe nas liberal democracias estáveis, um só exemplo de associação entre representação proporcional , multipartidarismo e presidencialismo"(ABRANCHES, 2018).

Um dos elementos que empregam bastante peso na necessidade dessa coalizão, é o multipartidarismo, pois aliado a possibilidade de coligações partidárias e a proporcionalidade, torna o poder partidário mais fragmentado, para termos ideia em 1988, apenas 4 partidos tinham mais de 5\% de representatividade na Câmara, atualmente 10 partidos tem esse índice, o que eleva o nosso grau de multipartidarismo para o nível alto, tornando o poder bastante difuso. Por isso, para manter a base de governo "o presidencialismo de coalizão organiza o ministério como amplas coalizões, promovendo um presidencialismo mitigado pelo controle parlamentar sobre o gabinete e que também constitui o gabinete" (ABRANCHES, 2018).

\section{$O$ capitão, a coalizão às avessas e o STF}

Evidencia-se que esse arranjo político imperfeito (presidencialismo de coalizão) funcionou até o final de 2018, quando a eleição presidencial do mesmo ano trouxe mais um ponto de inflexão, que foi a eleição do candidato considerado um outsider, proveniente do chamado baixo clero, que a época tinha migrado para um partido de baixa representação política no congresso para que pudesse ser candidato a presidência da república.

Com isso, chega ao poder em janeiro de 2019, um governo sem duas das formas de coalizão definidas por (ABRANCHES, 2018) que são: a coalizão pela constituição do governo e a coalizão por meio da aliança eleitoral.

Ademais não havia projeto de formar coalizão, pois como disse um de seus aliados ${ }^{2}$ a estratégia do Presidente eleito era buscar a governabilidade por influência das bancadas, mais especificamente da bancada evangélica, bancada ruralista e a bancada da bala ${ }^{3}$, o que na conta dele dava maioria absoluta na câmara,

Outra estratégia adotada pelo governo eleito, foi buscar apoio num antigo ator moderador, nomeando inúmeros militares para o primeiro, segundo e terceiro escalões. O tempo mostrou que essas estratégias não conseguiram blindar o governo de enfraquecimento e do surgimento de crises.

\footnotetext{
${ }^{2}$ Disse o Pastor Silas Malafaia numa live junto com o, então candidato Bolsonaro, no dia 04 de outubro de 2018.

${ }^{3}$ Parlamentares ligados a Segurança Pública 
O que existiu como resultado dessas duas estratégias, foi que ao longo do tempo o poder executivo foi perdendo força e colecionando derrotas jurídicas e políticas, isso logo no início do governo, o que contribuiu consideravelmente, para a instabilidade do governo, na medida que o poder de atração do chefe do executivo influencia no grau dos conflitos que podem surgir, e por essa força de atração ter uma relação direta com o seu apoio social, a sua popularidade e a avaliação do desempenho do seu governo. Quanto mais derrotas, quanto menor a popularidade, quanto pior for a avaliação do seu governo, menor vai ser a força de atração ao governo, provocando uma espécie de força centrípeta em relação a figura do Presidente, a ponto de o governo romper com a única coalizão presente no Governo, que era a coalizão do próprio partido, causando assim uma espécie de coalizão as avessas, ou seja, todos se uniram para limitar a governabilidade, causando um vácuo no exercício do poder.

Com o enfraquecimento do poder executivo, alguém ocuparia esse espaço, como os militares já estavam embarcados no governo, surgiram dois atores importantes no processo de limitação da autuação do governo, um já tinha experimentado e demonstrado essa força por ocasião da eleição e do impeachment de Collor, que era a mídia; e o outro que até pouco tempo (antes da constituição de 1988), tinha pouca expressividade no cenário político brasileiro, mas que vinha dando pequenos passos desde a abertura política , na medida que se posicionava para além das questões jurídicas, e com uma interpretação da Constituição que foi se tronando cada vez mais peculiar, transformando poder potencial em poder pontual, esse novo player era o Supremo Tribunal Federal.

\section{O STF, o intervencionismo e o semipresidencialismo de liminares}

O princípio da separação dos poderes ficou expresso no Artigo $2^{\circ}$ da CF88, o Artigo 84 inciso XVI e o Artigo 101, tratando da competência da nomeação e da Composição do STF respectivamente, já o Artigo 102 trata das competências do aludido tribunal. Pedro Vieira Mota nos diz que o papel do judiciário é modesto politicamente por duas razões, a primeira porque não se concebe ao judiciário posicionar-se no sentido de frear ou embargar outro poder, pois todo posicionamento do judiciário há de apresentar um conteúdo ético, que lhe é essencial, seus posicionamentos têm que ser justos e imparciais. Só isso já limita, consideravelmente, a capacidade de manobrar. A segunda, é porque o judiciário é o aplicador das leis por excelência, e seu trabalho consiste em aplicar as leis elaboradas pelo legislativo, com a participação do executivo, mas inteiramente à revelia do judiciário (MONTESQUIEU, 2008).

A Constituição de 1988 formalizou um arranjo diferente de muitas outras Cortes Constitucionais, atribuindo ao Supremo uma concentração de competências que suplantam a 
jurisdição constitucional mundo afora, as quais são: a de tribunal constitucional, a de foro judicial especializado, e a de tribunal de recurso de última instância. Além dessas competências, o Supremo foi ainda mais hipertrofiado por ocasião das Emendas Constitucionais no 3/93(que entre outras coisas, adicionava atribuições ao STF no artigo 102, e no 103 aumentava os autores que poderiam entrar com ação declaratória de constitucionalidade e ações diretas de inconstitucionalidade); e a n 45/05 (essa Emenda estendeu e muito o poder do STF, pois além de criar o efeito vinculante, aumentou os atores com possibilidade de ação declaratória de constitucionalidade e ações diretas de inconstitucionalidade) e ainda pelas Leis 9868/99 (Dispõe sobre o processo e julgamento da ação direta de inconstitucionalidade e da ação declaratória de constitucionalidade perante o Supremo Tribunal Federal.) e 9882/99(julgamento da arguição de descumprimento de preceito fundamental).

Com a capacidade de manobra aumentada pela Constituição e das leis subsequentes, o STF concentrou poderes, que o habilitava a dispor de usar desse poder concentrado, e se algo dispõe de um poder, ele vai (em algum momento) fazer uso desse recurso. Desse modo esse novo player surge forte no nosso cenário político, o que pode ser evidenciado nas palavras (BARROSO, 2015) "constitucionalismo significa em essência, limitação do poder e supremacia da lei”, ou ainda quando o mesmo Ministro afirma “que elas podem, legitimamente, empurrar a história”. Seja lá o que isso queira dizer, ele contradiz os dois papéis do judiciário defendido por Pedro Vieira Mota (MONTESQUIEU, 2008), mas corrobora com o que diz Benjamin Constant, pois “a ação executada em nome de todos, ficando necessariamente, por bem ou por mal, nas mãos de um indivíduo ou de uns poucos, resulta que, quando nos entregamos a todos os demais, por certo não estamos nos entregando a ninguém. Ao contrário, estamos nos rendendo àqueles que agem em nome de todos. A consequência é que, quando nos entregamos completamente, não participamos de condição universalmente igual, de vez que algumas pessoas lucram exclusivamente com o sacrifício do restante" (Apud CAMPOS, 2019).

A escalada intervencionista do STF começou de forma discreta, ainda no Governo Itamar, quando em 1994 o STF mudou a regra de conversão dos salários em URV, e concedeu um auto aumento dos vencimentos dos juízes e funcionários em 11\%, e em 1998, quando o Ministro Marco Aurélio Melo suspendeu, em caráter liminar, uma indicação de FHC ao Superior Tribunal Militar (ZAVERUCHA,2000). Mas a notoriedade veio por ocasião da Ação Penal 470, popularmente conhecida como Mensalão, na qual a face dos ministros do supremo foi exposta, concedendo assim, uma fama repentina a servidores antes vistos como reservados.

Com o passar do tempo, existiram outros posicionamentos do STF, por ocasião da operação lava jato e também pelo impeachment da Presidente Dilma Rousseff, que terminaram por colocá-lo 
em condições de assumir posição de destaque no cenário político nacional, o que foi superdimensionado no atual governo. Demonstrando uma forte inclinação em enfrentar o executivo federal, o STF atraiu inúmeros partidos a ingressarem com ações limitando ou anulando a atuação do governo, já que enquanto diversos fatores faziam com que o Presidente exercesse força centrífuga, o STF e sua demonstração de força combativa passou a exercer força centrípeta, e para manter uma coalizão a força centrípeta é essencial (ABRANCHES, 2018). Em linhas gerais surge o exercício do governo permitido, consolidando uma partilha do poder, algo similar a um semipresidencialismo, que aqui defino como um semipresidencialismo de liminares, uma forma imperfeita e não escrita do presidencialismo que apresenta algumas características para que possa acontecer, sejam elas: a existência de um governo (poder executivo) sem alianças partidárias, ou ainda com alianças frouxamente articuladas; a existência de uma oposição inclinada a judicializar junto a Suprema Corte todo e qualquer movimento do governo; uma Suprema Corte porosa a judicialização, e ainda o ativismo judicial do STF. Como exemplo disso, podemos ver que só no ano de 2020 foram 300 ações impetradas no STF por partidos de oposição: PDT-49, Rede- 44, PSB-43, PT-42 e PSOL-30.

\section{O intervencionismo, as inconstitucionalidades e a confissão.}

$\mathrm{Na}$ intenção de formular uma linha do tempo enumeraremos algumas ações e decisões que foram se acumulando após o início dos anos 2000, e caminharam numa escalada nunca vista , especialmente após a eleição de 2018 e a posse do governo em janeiro de 2019, para a intervenção em outros poderes, a ponto de conceder a Suprema Corte a posição de copresidente da república federativa do Brasil, conforme veremos:

1. A Constituição de 1988 trata do que antes era definido como "disciplina partidária" no parágrafo primeiro de seu Art. 17, mas sem propor sanções para o caso de descumprimento, nem tampouco, havia definição de sanção em normas infraconstitucionais. Alegando inercia do legislativo, quanto as constantes mudanças de partidos dos parlamentares o STF fez constar na decisão do MS $n^{\circ}$ 26604 que o TSE adotasse uma resolução que disciplinasse a fidelidade partidária. Como resultado o Tribunal Superior Eleitoral editou, em 25 de outubro de 2007, a Resolução nº 22.610, que previa as hipóteses de justificação para a desfiliação do partido pelo qual o mandatário fora eleito e ainda estipulando a sanção de perda de mandato para aqueles que não cumprissem a citada resolução para se desfiliarem, criando assim uma legislação nova sem a participação do legislativo; 
2. Com o advento do processo do mensalão, e algumas outras ações de combate a corrupção, muitos políticos passaram a figurar nos noticiários nacionais sendo conduzidos pela polícia, onde os policiais faziam o uso de algemas para a referida condução, fato que provocou uma resposta, e essa resposta veio por meio da aprovação em plenário do Supremo em agosto de 2008 da Súmula Vinculante $\mathrm{n}^{\circ} 11$, a qual disciplinava o uso de algemas por ocasião da prisão determinado que só seria lícito o uso de algemas em casos de resistência e de fundado receio de fuga ou de perigo à integridade física própria ou alheia, por parte do preso ou de terceiros, sob pena de nulidade da prisão ou do ato processual a que se refere, sem prejuízo da responsabilidade civil do Estado. Assim, mais uma vez por intervenção do STF, surge (na prática) uma nova legislação no âmbito do Processo Penal Brasileiro;

3. Após inúmeros escândalos envolvendo políticos, parentes e apadrinhados, a sociedade já não aceitava determinadas nomeações para cargos públicos, diante dessa nova situação, a Suprema Corte tomou a iniciativa de legislar mais uma vez, e em outubro de 2008, institui a Súmula Vinculante $\mathrm{n}^{\circ}$ 13, que na prática dava nova interpretação ao chamado Nepotismo, alegando violação a constituição a Suprema Corte, acabou por legislar novamente;

4. O Congresso Nacional aprova a Lei 12.034/09 que tratava da reforma eleitoral, e dentro da mesma, em seu Art. $5^{\circ}$, determinava a impressão dos votos com o objetivo de permitir a conferência do funcionamento do sistema eletrônico de votação pelos partidos políticos, o que deveria funcionar para eleição de 2012, destarte. por intermédio da relatora a Ministra Cármen Lúcia, foi inviabilizada sua aplicabilidade, devendo então a impressão do voto ser utilizada na eleição de 2014, o quer mais uma vez não aconteceu, por causa da decisão unânime do plenário do STF, contrariando lei aprovada pelo legislativo;

5. Em dezembro de 2015 foi dado início o processo de afastamento da então Presidente Dilma Rousseff, o qual mudaria o desenho político nacional, com a alteração da linha sucessória, ou seja, no momento que o Chefe do Poder Executivo se afastasse do exercício, por motivo de saúde ou viagem, o primeiro na linha sucessória seria o Presidente da Câmara dos Deputados, a época o Deputado Federal pelo Rio de Janeiro, Eduardo Cunha, o qual teria dado início ao processo de impeachment da Presidente Dilma. Nesse contexto, e por se encontrar na condição de investigado pela Operação Lava Jato, e ainda ser acusado pela PGR de interferir nas investigações contra si, o STF por unanimidade acatou o pedido da PGR e em maio de 2016 afastou o aludido deputado do exercício do seu mandato e consequentemente da presidência da Câmara dos Deputados, fato nunca vivenciado na história brasileira, o que abriu precedente para meses depois, em dezembro do mesmo 
ano, o STF determina o afastamento do Presidente do Senado, o Senador, pelo estado de Alagoas, Renan Calheiros , em virtude de ter se tornado réu na Operação Lava Jato;

6. Por ocasião do processo e julgamento da Presidente da República por crime de responsabilidade, processo que é disciplinado pela Lei 1079/50, na qual determina que por ocasião da condenação por crime de responsabilidade, a pena está prevista pelo Artigo 33 da mencionada Norma. A qual inabilita o condenado por oito anos para o exercício de qualquer função pública. Todavia ao presidir o processo, o Ministro Levandowisk, terminou por deliberar pelo "fatiamento" do impeachment da Presidente Dilma, a ponto de abrir a possibilidade no Senado da existência de duas votações em separado, uma pela condenação do criem de responsabilidade e outra para manutenção ou não dos direitos políticos dela. Nesse caso, específico, o STF inaugura uma ferramenta que será utilizada outras vezes, que é a interpretação de exegese.

7. O critério do trânsito em julgado, foi formalizado na nossa Carta Magna, nesse caminho, no ano de 2009 , o STF ratificou o entendimento e considerou inconstitucional o cumprimento antecipado da pena, porém no ano de 2016 , por 7 votos a 4 , o plenário do Supremo alterou a jurisprudência e tornou possível a prisão em segunda instância, decisão que possibilitou a prisão do ex-Presidente Lula no ano de 2017, além de outros mais 100 condenados pela Operação Lava Jato, todavia em 2019, o mesmo objeto é fruto de mais uma análise , e por 6 votos a 5 , o Supremo alterou novamente o seu entendimento de 2016, e proibiu a prisão após a condenação em 2a. instância.

8. Mesmo o inquérito policial sendo um procedimento persecutório de caráter administrativo instaurado pela autoridade policial, que tem como destinatários imediatos o Ministério Público, em março de 2019 o STF instaura de ofício o inquérito 4781, mediante uma interpretação criativa do Art. 43 do Regimento Interno do próprio STF. Inquérito esse, que tem como objetivo apurar o cometimento de um crime que não existe tipificação penal, no nosso ordenamento jurídico, a divulgação de notícias falsas, o que ficou conhecido como o inquérito das Fake News, fato que inaugura o tribunal de exceção, em virtude do procedimento violar diversos princípios do nosso ordenamento, como: o Princípio da especialidade, o princípio do Juiz Natural, a violação do sistema acusatório, entre outros.

9. Se existe a possibilidade de abusar do poder, alguém vai fazer, essa premissa foi ratificada quando a Revista Crusoé publica, em abril de 2019, uma edição que traz na capa o título “ O amigo do Amigo do meu pai”, chega a redação da, um oficial de justiça com a determinação do ministro Alexandre de Moraes para que o periódico retirasse imediatamente do ar a reportagem que relacionava o Ministro Dias Toffoli com comportamentos pouco republicanos com a Empreiteira 
Odebrecht, além dessa decisão, determinava o prazo de 72h para que os responsáveis pela publicação prestassem depoimento na Polícia Federal, o que na prática era uma censura a liberdade de imprensa garantida no parágrafo primeiro do Art. 220 da Constituição Federal de 1988.

10. Alegando mais uma vez inércia do Legislativo, e recepcionando o Mandado de Injunção 4.733, ações protocoladas pelo PPS e pela Associação Brasileiras de Gays, Lésbicas e Transgêneros (ABGLT), em junho de 2019 o STF iguala o que os proponentes classificam como homofobia (em virtude de considerar o público que representam como uma "raça social") ao crime de racismo previsto no artigo 20 da Lei 7.716/1989. Na prática a Suprema Corte cria um tipo penal novo, sem que tenha existido uma lei anterior que o defina.

11. Sendo o Irã uma nação sob embargo econômico do governo americano, a estatal Petrobras , em conformidade com a política externa adotada pelo governo em exercício, se negou a abastecer dois navios daquele pais que estavam parados no porto de Paranaguá , tendo havido uma primeira decisão por parte do Tribunal de Justiça do Paraná, a citada estatal recorreu, e chegando ao STF , o Ministro Dias Toffoli determinou o abastecimento , alegando que não haveria risco a soberania nacional, em virtude do abastecimento acontecer decorrente de uma decisão judicial, mas a decisão ia de encontro a política externa já mencionada.

12. Ainda era agosto de 2019, quando o Ministro Alexandre de Moraes, usando o "guarda-chuva" do Inquérito 4781(Inquérito das Fake News), determinou o a suspensão de uma investigação da Receita Federal que apurava movimentação financeira atípica de 133 pessoas e dentre essas pessoas, estavam o Ministro Gilmar Mendes e a esposa do ministro Dias Toffoli, determinando ainda o afastamento dos dois funcionários responsáveis pela investigação. Utilizando da alegação que haviam "claros os indícios de desvio de finalidade na apuração da Receita Federal, que, sem critérios objetivos de seleção", não passando de mera alegoria para justificar a ação de "presidente" do inquérito, tal alegação faz uso da máxima “ acuse-os do que você faz, xingue-os do que você é”.

13. Em entrevista à Revista Veja publicada da edição no. 2647 em 14 de agosto de 2019, o Ministro Dias Toffoli, dá o primeiro sinal explícito do papel que o STF teria assumido, no vácuo do folclórico poder moderador, a Suprema Corte se viu em condições de assumir esse "pesado encargo", conforme palavras do entrevistado "um exemplo de como o poder moderador do Judiciário pode agir para evitar rupturas e preservar a estabilidade da democracia.”, e ainda "O Supremo deve ter esse papel moderador, oferecer soluções em momentos de crise. Estávamos em uma situação de muita pressão, com uma insatisfação generalizada. Mas o pacto funcionou. A reforma da Previdência foi aprovada, as instituições estão firmes. Agora o grande desafio é o país voltar a crescer." 
14. Em março de 2020 , a presidência da república edita a Medida Provisória no 929/2020, no intuito de alterar a Lei $\mathrm{n}^{\circ} 13.979$, de 6 de fevereiro de 2020, visando atacar diretamente o Art. $3^{\circ}$ da referida MP, o qual tratava sobre a continuidade de serviços e atribuía a decreto presidencial decidir quais serviços seriam considerados essenciais, assim atendendo contestação de mais um partido de oposição, a decisão colegiada (unânime) da Suprema Corte , redefiniu os poderes de polícia sanitária, dando aos estados e municípios a possibilidade de determinarem suas formas de enfrentamento a crise do covid-19, tal interferência do Supremo, terminou por hipertrofiar a autonomia constitucional dos estados e municípios, esvaziando os poderes do governo Bolsonaro sobre a definição de quais atividades não poderiam ser afetadas pelas medidas de isolamento;

15. Em março de 2020, o Ministério das Relações exteriores, determinou a remoção dos diplomatas brasileiros da Venezuela, pois segundo o governo brasileiro não reconhecia Nicolas Maduro como Presidente daquele país e sim Juan Guaidó, e em contrapartida exigia que aquele governo fizesse o mesmo com os 34 diplomatas venezuelanos, que se encontravam no Brasil, traduzindo os diplomatas seriam expulsos do país, mas atendendo pedido de um parlamentar de oposição o Ministro Luís Roberto Barroso, suspendeu a decisão do Ministro das Relações Exteriores;

16. Em abril de 2020, o Ministro Alexandre de Moraes, alegando desvio de finalidade determina a suspensão da nomeação do Diretor Geral da Polícia Federal, ato do poder executivo amparado pelo Art. $2^{\circ}$ - C da Lei $n^{\circ}$ 9.266/1996, que reorganiza as classes da Carreira Policial Federal, dispõe que O cargo de Diretor-Geral, nomeado pelo Presidente da República, é privativo de delegado de Polícia Federal integrante da classe especial; e pela CF88 em seu Art. 84. Que trata da competência privativa do Presidente da República para nomear Ministros do Supremo Tribunal Federal e dos Tribunais Superiores, os Governadores de Territórios, o Procurador-Geral da República, o presidente e os diretores do banco central e outros servidores, quando determinado em lei;

17. Em junho de 2020, atendendo pedido de ONGs e de mais um partido de oposição, o Ministro Edson Fachin, utilizando o advento da crise do covid-19, cria uma zona de exclusão ${ }^{4}$ institucionalizada no Brasil, quando proíbe operações policiais nas comunidades carentes do Rio de Janeiro em quanto durasse a crise sanitária.

\footnotetext{
${ }^{4}$ Uma zona de exclusão é uma divisão territorial estabelecida para vários propósitos específicos de cada caso. De acordo com o Departamento de Defesa dos Estados Unidos, uma zona de exclusão é um território onde o órgão sancionador proíbe atividades específicas em uma área geográfica específica. Essas zonas são criadas para controle de populações para fins de segurança, controle de multidões ou militares, ou como zona de fronteira, e podem ser temporárias ou permanentes.
} 
18. Em julho de 2020, mais uma vez utilizando o Inquérito das Fake News, o Ministro Alexandre de Moraes determina que contas de apoiadores do Presidente sejam suspensas, não satisfeito determinou a extensão da sua decisão para que alcançasse também que contas no exterior, alegando que existindo no exterior, eles burlavam a sua primeira decisão. Faz-se necessário lembrar mais uma vez que não existe o tipo penal Fake News;

19. m Dezembro de 2020, o Ministro Luiz Edson Fachin, interfere num ato discricionário do Poder Executivo e para fazê-lo alega "Incumbe ao Estado diminuir a necessidade de se ter armas de fogo por meio de políticas de segurança pública que sejam promovidas por policiais comprometidos e treinados para proteger a vida e o Estado de Direito.", ou seja , sem nenhum estudo , sem ouvir nenhum especialista em segurança pública, bem como, sem estar escrito em nenhuma norma que é missão do Estado reduzir o número de armas; numa decisão monocrática, o aludido ministro ,suspendeu a Resolução 126/2020, que zerou a alíquota de importação de revólveres e pistolas, o que nos leva a crer que nada mais foi do que imposição do Ministro;

20. Após divulgar um vídeo nas redes sociais criticando ministros do Supremo, em fevereiro de 2021, o Ministro Alexandre de Moraes, fazendo uso do Inquérito das Fake News, manda prender em flagrante o Deputado Daniel Silveira, alegando que eram necessárias medidas enérgicas para impedir que o parlamentar continuasse cometendo crime, só que o crime em questão é a opinião de um congressista , amparada no Art. 53 da Constituição. Além de criar a imunidade parlamentar relativa, o Supremo criou o flagrante perpétuo, alegando que a exposição nas redes sociais é um crime que não finda;

21. Considerando a Justiça Federal do Paraná incompetente para julgar as ações relacionadas ao ex-Presidente Lula, em março de 2021, em caráter liminar, o Ministro Edson Fachin, altera suas decisões anteriores referentes ao mesmo objeto, e devolvendo a elegibilidade do ex-Presidente, já que ele se encontrava em liberdade em virtude da decisão da proibição da prisão em segunda instância, agora se encontrava em pleno gozo dos direitos políticos, decisão ratificada no pleno do STF;

22. Em abril de 2021, a Ministra Rosa Weber, atendendo pedido de cinco partidos de oposição, suspendeu partes de quatro decretos assinados pelo Presidente Jair Bolsonaro que flexibilizavam a posse e o porte de armas, o que tinha sido promessa de sua campanha, a decisão foi fundamentada no argumento de que a livre circulação de pessoas armadas e carregando consigo várias armas de fogo atenta contra o direito constitucional da livre reunião em espaço público de forma pacífica, sendo que 
tal argumento não encontra base em nenhuma norma do nosso ordenamento jurídico, o que nos leva a crer, mais uma vez, que foi pura imposição da Ministra;

23. Interferindo mais uma vez em questões do legislativo, dessa vez no que é definido como interna corporis ${ }^{5}$, interferindo diretamente no senado determinado a abertura de uma CPI, no que seria decisão exclusiva do Presidente da casa, o Luiz Roberto Barroso , acata pedido de mais um partido de oposição ao governo, "Defiro o pedido liminar para determinar ao Presidente do Senado Federal a adoção das providências necessárias à criação e instalação de comissão parlamentar de inquérito", sendo que o Senado já havia defendido, por meio de documentação enviada a corte , que a prerrogativa de decidir o momento de abertura da CPI é do presidente da Casa;

24. Contrariando recomendação da Procuradoria Geral da República, em junho de 2021, o STF decide que só o Presidente da República e seus ministros, deveriam ser alvo da CPI do covid-19, pois na medida em que proíbe que governadores e prefeitos sejam investigados na comissão parlamentar, resta apenas o executivo nacional a ser investigado;

25. Em junho de 2021, por ocasião do voto impresso ter entrado na pauta do debate político, o Presidente do TSE, o Ministro Luiz Roberto Barroso se reúne com líderes de11 partidos, que totalizavam 326 deputados e 55 senadores, no intuito de que não fosse aprovada a PEC-135, a qual tratava da adoção do voto impresso, segundo informações dos veículos de imprensa , os Ministros Gilmar Mendes, Alexandre de Moraes e Luiz Roberto Barroso, atuaram para demover os partidos da ideia de aprovar o voto impresso;

26. Após o Presidente da República, fazer um vídeo ao vivo na internet, afirmando a impossibilidade de auditagem do processo eleitoral brasileiro, em virtude da utilização das urnas eletrônicas , como também a apresentação de um relatório do próprio TSE, informando que o sistema tinha sido invadido durante o processo eleitoral de 2018, o Ministro Alexandre de Moraes , determina a inclusão da referida autoridade no inquérito das Fake News, o que se traduz em investigação do chefe do executivo, de forma divergente ao processo definido no ordenamento jurídico nacional;

27. O ministro Alexandre de Moraes, em agosto de 2021, determina a prisão preventiva do exdeputado e presidente nacional do PTB Roberto Jefferson, alegando que ele tinha cometido diversos crimes, por ocasião da publicação de diversos vídeos criticando ministros do STF, tal decisão fez uso

\footnotetext{
5 "Interna Corporis" são questões que devem ser resolvidas internamente por cada poder, sendo questões próprias de regimento interno; ex.: cassação de um deputado ou senador por falta de decoro parlamentar
} 
mais uma vez do Inquérito das Fake News. Tal decisão, como tantas outras, vai de encontro ao princípio do Juiz Natural, pois o afetado em questão não possui prerrogativa de foro;

28. Mesmo o direito ao trabalho remunerado ser uma direito garantido pela Constituição, ainda em agosto de 2021 , o TSE alegando "críticas ilegítimas" ao processo eleitoral, e mesmo o aludido órgão tendo a atribuição de coordenar os trabalhos eleitorais do país e realizar a diplomação do Presidente e vice-Presidente da República, a Corte Eleitoral também tem como atribuições julgar recursos interpostos contra as decisões dos Tribunais Regionais Eleitorais (TREs) e responder às consultas sobre matéria eleitoral feitas por autoridades com jurisdição federal ou órgão nacional de partido político, e mesmo não se tratando de ano eleitoral ou campanha eleitoral; determina a retirada da fonte de receita de diversos canais da internet (todos apoiadores do Presidente)

29. Por ocasião do dia 07 de setembro de 2021 , políticos, empresários e apoiadores do Presidente da república convocavam a, pelo menos 15 dias, manifestação em diversas cidades espalhadas pelo Brasil , o que logo foi visto como uma ameaça ao estado democrático de direito , contrariando o princípio de livre reunião de livre manifestação previstos na nossa Carta Magna, não satisfeitos pela classificação da manifestação como "atos antidemocráticos" o Ministro Alexandre de Moraes toma algumas decisões , a seguir: Determina busca e apreensão nas casas de líderes do movimento de 7 de setembro, incluindo o cantor e ex-deputado federal Sérgio Reis, e Antonio Galvan (APROSOJA), por crime de opinião; Proíbe líderes do movimento de 7 de setembro de se aproximarem da Praça dos 3 Poderes; Proíbe vaquinha para pagamento de carros de som e despesas do movimento de 7 de setembro; Expede mandados de prisão para o Jornalista Evaldo Eustaquio e o líder dos Caminhoneiros Zé Trovão, alegando que eles estavam convocando os atos nas redes sociais;

30. Em setembro de 2021, por ocasião de ter participado de um congresso conservador, Jason Miller, ex-conselheiro do ex-Presidente americano Donaldo Trump, foi detido pela Polícia Federal em Brasília. $\mathrm{O}$ empresário foi detido para prestar depoimento à $\mathrm{PF}$, por determinação do ministro do Supremo Tribunal Federal Alexandre de Moraes, sobre suposta participação na organização de atos antidemocráticos. Podemos traduzir o fato como a detenção de um cidadão americano, sem o cometimento de crime definido;

31. Acatando pedido de mais um partido de oposição ao governo, em setembro de 2021 , o Ministro Ricardo Lewandowsky, decide em caráter liminar, suspender decisão do Ministério da Saúde da não aplicação da vacina em pessoas maiores de 12 anos, decisão que depois foi ratificada 
pelo colegiado da Corte. A decisão do Ministério da Saúde tinha embasamento na orientação da recomendação da Câmara Técnica Assessora em Imunização e Doenças Transmissíveis e da Organização Mundial de Saúde (OMS). Sem nenhum conhecimento técnico, o Ministro Lewandowsky autoriza que estados e municípios iniciassem a vacinação do aludido público;

32. Em outubro de 2021, atendendo pedido de mais um partido de oposição, o Ministro Gilmar Mendes suspende parte da Lei de Improbidade Administrativa, e redefine o texto da mesma lei quando define que a sanção prevista só seria aplicável no caso do cometimento da improbidade ser na forma dolosa. Na prática o Ministro vetou parte da lei, e foi além dando novo sentido (legislando) a mesma, diferentemente do que o legislativo tinha decidido;

33. Em novembro de 2021, no $9^{\circ}$ Fórum Jurídico de Lisboa, em Portugal, o Ministro Dias Toffoli , assume em público que o Brasil já vive de fato um semipresidencialismo "Nós já temos um semipresidencialismo com um controle de poder moderador que hoje é exercido pelo STF”, e acrescenta , "Basta verificar todo esse período da pandemia", em linha gerais o Ministro confessa que desde março de 2020 , o presidencialismo foi corrompido de sua forma original, pelo órgão que deveria defender a Constituição;

34. Mesmo o Art. 13 da Constituição vigente, determinando expressamente, que o Português é a língua oficial do Brasil, e mesmo uma lei tendo sido votada e aprovada na Assembleia Legislativa do Estado de Rondônia , em Novembro de 2021, o Ministro Edson Fachin , intervém liminarmente na legislação aprovada pela casa que representa o povo daquele estado da federação, alegando que a pretexto de defender a norma culta a lei terminava por impor um tipo de censura prévia, na medida que impede as pessoas de se expressarem;

\section{Conclusão}

Diante dos fatos apresentados verifica-se que ao longo dos últimos anos a Suprema Corte vem por diversas vezes invadindo a competência dos outros poderes da república, fato que se intensificou a partir de janeiro de 2019, e diante de sua porosidade em aceitar demandas e do forte ativismo judicial verificado pela expressão empurrar a história , terminou por se tornar uma ferramenta do congresso (Partidos de oposição) para governar junto com o poder executivo, é fácil perceber essa influência da oposição, pois se formos verificar quantas ações dos governistas ou do próprio governo prosperaram, teremos um retrato da quase exclusividade do poder liminar, nas mãos dos partidos contrários ao governo. 
Nos regimes semipresidencialistas institucionalizados o exercício do governo é partilhado entre o poder executivo e o legislativo, cada um tendo suas competências definidas em lei, proibindo assim, que um poder invada a competência do outro. No Brasil, mais uma vez é criada uma situação peculiar ao nosso folclore político, uma espécie de presidencialismo imperfeito, ao qual podemos denominar como semipresidencialismo de liminares, pois através de liminares e decisões monocráticas dos ministros do STF, a oposição tem conseguido impor sua agenda de governo frente ao poder executivo legitimamente eleito. O regime não institucionalizado que antes andava pelas sombras, agora é bradado aos quatro cantos do mundo pelos próprios executores do modelo imperfeito.

\section{REFERÊNCIAS}

AGÊNCIA BRASIL, Gilmar Mendes suspende parte da lei de improbidade administrativa. Brasília, 03 outubro de 2021.<https://agenciabrasil.ebc.com.br/justica/noticia/2021-10/gilmarmendes-suspende-parte-da-lei-de-improbidade-administrativa $>$ Acessado em 12 de novembro de 2021.

BBC NEWS, STF confirma anulação de condenações da Lava Jato contra Lula - entenda, 15 de abril de 2021.<https://www.bbc.com/portuguese/brasil-56768338> Acessado em 12 de novembro de 2021.

BARROSO, Luís Roberto. Curso de direito constitucional contemporâneo: os conceitos fundamentais e a Construção do novo modelo. 5. ed. São Paulo: Saraiva, 2015.

, Luís Roberto. A razão sem voto: o Supremo Tribunal Federal e o governo da maioria. Revista Brasileira de Polítcas Públicas. Vol.5. UNICEUB, 2015.

BRASIL. Constituição (1824) Constituição Política do Império do Brazil. Rio de Janeiro,1824. Disponível em< http://www.planalto.gov.br/ccivil_03/constituicao/constituicao24.htm>. Acessado em 16 de setembro de 2021.

. Constituição (1891) Constituição da República dos Estados Unidos do Brasil. Rio de Janeiro,1891.Disponível em<http://www.planalto.gov.br/ccivil_03/constituicao/constituicao91.htm> Acessado em 16 de setembro de 2021.

Constituição (1937) Constituição da República dos Estados Unidos do Brasil.Rio de

Janeiro, 1937. Disponível <https://www.planalto.gov.br/ccivil_03/constituicao/constituicao37.htm> Acessado em 16 de setembro de 2021.

Constituição (1967) Constituição da República Federativa do Brasil. Brasília, 1967.Disponível em < https://www.planalto.gov.br/ccivil_03/constituicao/constituicao67.htm> Acessado em 16 de setembro de 2021. 
. Constituição (1988) Constituição da República Federativa do Brasil. Brasília, 1988.Disponível em <http://www.planalto.gov.br/ccivil_03/constituicao/constituicao.htm> Acessado em 16 de setembro de 2021.

. Constituição (1988) Emenda a Constituição no 03, de 17 de março de 1993. Brasília. Disponível em <http://www.setorgrafico.org.br/legislacao/emenda_constitucional/ec3.pdf> Acessado em 13 de setembro de 2021.

Constituição (1988) Emenda a Constituição $n^{\circ} 45$, de 30 de dezembro de 2004.

Brasília.

Disponível

em

<http://www.planalto.gov.br/ccivil_03/constituicao/emendas/emc/emc45.htm> Acessado em 13 de setembro de 2021.

CÂMARA DOS DEPUTADOS, Deputado Daniel Silveira é preso por ordem do Ministro Alexandre de Moraes, 17 de fevereiro de 2021.<https://www.camara.leg.br/noticias/728380deputado-daniel-silveira-e-preso-por-ordem-do-ministro-alexandre-de-moraes/ > Acessado em $15 \mathrm{de}$ novembro de 2021.

CAMPOS, Gabriel Afonso. Poder Neutro e razão de Estado em Benjamin Constant. Revista de Ciências do Estado. Belo Horizonte: v. 4, n. 1, 2019, e5150. ISSN: 2525-8036.

CONECTAS, Entenda as razoes que levaram o stf a regular operações policiais em favelas do rio, 29 de junho de 2020. https://www.conectas.org/noticias/entenda-as-razoes-que-levaram-o-stf-aregular-operacoes-policiais-em-favelas-do-rio/ Acessado em 12 novembro de 2021.

CONSULTOR JURÍDICO, Fatiamento do impeachment causa sua nulidade e STF deveria refazê-lo. 17 de setembro de 2016. <https://www.conjur.com.br/2016-set-17/fatiamentoimpeachment-causa-nulidade-stf-deveria refaze-lo > Acessado em 16 de novembro de 2021.

, Supremo aprova equiparação de homofobia a crime de racismo.13

de junho de $2019<$ https://www.conjur.com.br/2019-jun-13/stf-reconhece-criminalizacao-

homofobia-lei-racismo> Acessado em 16 de novembro de 2021.

armas.

, Fachin suspende resolução que zerou imposto na importação de

14 de dezembro de 2020<https://www.conjur.com.br/2020-dez-14/fachin-suspende-aliquota-zeroimportacao-armas> Acessado em 18 de novembro de 2021.

Roberto Jefferson, aliado de Bolsonaro, é preso por ordem do ministro Alexandre, do STF. 13 de agosto de 2021<https://www.conjur.com.br/2021-ago13/alexandre-manda-prender-roberto-jefferson-aliado-bolsonaro> Acessado em 18 de novembro de 2021.

CRUSOÉ, Urgente: Ministro do STF censura Crusoé,15 de abril de 2019. <https://crusoe.com.br/diario/urgente-ministro-do-stf-censura-crusoe/> Acessado em 17 de novembro de 2021. 
DW, Rosa Weber anula Partes de decretos de Bolsonaro sobre armas, 13 de abril de 2021. <https://www.dw.com/pt-br/rosa-weber-anula-partes-de-decretos-de-bolsonaro-sobre-armas/a57182209> Acessado em 13 de novembro de 2021.

EL PAIS, Cunha, o primeiro deputado da história afastado pelo STF. Brasíla 06 de maio de 2016. $<$ https://brasil.elpais.com/brasil/2016/05/06/politica/1462487188_422479.html> Acessado em $17 \mathrm{de}$ novembro de 2021.

EL PAIS, Renan é afastado da presidência do Senado após tornar-se réu por peculato. São Paulo , 07 de dezembro de $2016<$ https://brasil.elpais.com/brasil/2016/12/05/politica/1480970887_110529.html> Acessado em 17 de novembro de 2021.

ESTADO DE MINAS, Presidentyes de 11 partidos fecham acordo contra voto impresso, 26 de junho

de2021.<https://www.em.com.br/app/noticia/politica/2021/06/26/interna_politica, 1280873/presiden tes-de-11-partidos-fecham-acordo-contra-voto-impresso.shtml> Acessado em 17 de novembro de 2021.

MARTINS,Yves Gandra. Artigo 142 da Constituiçãa brasileira. Disponível em< https://www.conjur.com.br/2020-mai-28/ives-gandra-artigo-142-constituicao-brasileira>Acessado em 13 de setembro de 2021.

MONTESQUIEU, Charles de Secondat, Baron de, 1689-1755. O espírito das leis: a forma de governo, a federação, a divisão dos poderes / Montesquieu; introdução, tradução e notas de Pedro Vieira Mota. - 9. ed. - São Paulo: Saraiva, 2008.

PAIM, Antônio. Benjamin Constant e o ideário positivista. Disponível em <https://espacodemocratico.org.br/personagens/benjamin-constant-e-o-ideario-positivista-no-meio-

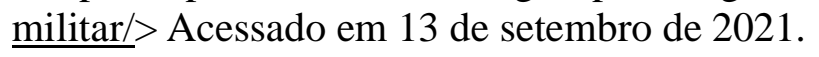

PLENO NEWS, Declaração de Toffoli sobre semipresidencialismo no Brasil é um escândalo, 16 de novembro de 2021.<https://pleno.news/opiniao/marisa-lobo/declaracao-de-toffoli-sobresemipresidencialismo-no-brasil-e-um-escandalo.html > Acessado em 17 de novembro de 2021.

PODER 360, Lewandowski diz que estados podem decidir sobre vacinação de adolescentes, 21 de setembro de 2021. $<$ https://www.poder360.com.br/justica/lewandowski-diz-que-estados-podemdecidir-sobre-vacinacao-de-adolescentes/> Acessado em 12 de novembro de 2021.

PORTAL G1, Moraes suspende apuração da Receita por suspeita de quebra de sigilo de ministros do STF. Brasília,01 de agosto de 2019. < https://g1.globo.com/politica/noticia/2019/08/01/moraes-suspende-apuracao-e-manda-receitaafastar-servidores-por-suspeita-de-quebra-de-sigilo-de-ministros.ghtml> Acessado em 16 de novembro de 2021.

Ministro do STF suspende expulsão de 34 diplomatas venezuelanos do Brasil. Brasília, 02 se maio de 2020. <https://g1.globo.com/politica/noticia/2020/05/02/ministro-do-stf-suspende-expulsao-de-34-diplomatas-venezuelanos-do-brasil.ghtml $>$ Acessado em 17 de novembro de 2021. 
Barroso determina que Senado instale CPI da Pandemia. Brasília, 08 de abril de 2021<https://g1.globo.com/politica/noticia/2021/04/08/barroso-determina-que-senado-instale-cpida-pandemia.ghtml > Acessado em 12 de novembro de 2021.

, Moraes inclui Bolsonaro em inquérito das fake news por ataques às urnas eletrônicas. Brasília, 04 de agosto de 2021. <https://g1.globo.com/politica/noticia/2021/08/04/moraes-inclui-bolsonaro-em-inquerito-de-fake-news-por-ataques-as-urnas-eletronicas.ghtml> Acessado em 12 de novembro de 2021.

, Moraes determina bloqueio de contas de bolsonaristas em redes sociais no exterior. Brasília , 30 de julho de 2020.<https://g1.globo.com/politica/noticia/2020/07/30/moraes-amplia-alcance-de-decisao-que-mandou-redes-sociais-retirarem-do-ar-contas-de-16-apoiadores-de-bolsonaro.ghtml> Acessado em 12 de novembro de 2021.

PORTAL R7, Ex-conselheiro de Trump é detido pela PF no aeroporto de Brasília. Brasília, 07 de setembro de 2021.<https://noticias.r7.com/brasilia/ex-conselheiro-de-trump-e-detido-pela-pf-noaeroporto-de-brasilia-07092021> Acessado em 13 de novembro de 2021.

REPOLÊS, Maria Fernanda Salcedo. Quem deve ser o guardião da constituição? Do poder moderador ao Supremo Tribunal Federal. Belo Horizonte: Mandamentos, 2008.

ROCHA, William Barbosa. A ilegalidade do inquérito das Fake News - INQ 4781. Dezembro de 2020, disponível em <https://jus.com.br/artigos/87235/a-ilegalidade-do-inquerito-das-fake-newsinq-4781> Acessado em 16 de novembro de 2021.

TRIBUNAL SUPERIOR ELEITORAL, Você sabe qual é a função do Tribunal Superior Eleitoral? O Glossário Eleitoral desta semana explica, 06 de janeiro de 2021. https://www.tse.jus.br/imprensa/noticias-tse/2021/Janeiro/voce-sabe-qual-e-a-funcao-do-tribunalsuperior-eleitoral-o-glossario-eleitoral-desta-semana-explica Acessado em 12 de novembro de 2021.

UOL, STF dá poder a estados para atuar contra covid-19 e impõe revés a Bolsonaro, Brasília 15 de abril de $2020<$ https://noticias.uol.com.br/saude/ultimas-noticias/redacao/2020/04/15/stf-tem-4votos-a-favor-de-autonomia-de-governadores-durante-a-pandemia.htm> Acessado em 17 de novembro de 2021.

Veja que canais tiveram monetização suspensa pelo TSE por desinformação. São Paulo , 17 de agosto de $2021<$ https://noticias.uol.com.br/politica/ultimas-noticias/2021/08/17/veja-lista-deperfis desmonetizados-pelo-tse-em-inquerito-sobre-fake-news.htm> Acessado em 12 de novembro de 2021.

VEJA, Dias Toffoli: 'O STF deve oferecer soluções em períodos de crise', 09 de agosto de 2019 <https://veja.abril.com.br/politica/dias-toffoli-o-stf-deve-oferecer-solucoes-em-periodos-de-crise/> Acessado em 12 de novembro de 2021. 